\title{
1. \\ O NEKIM ZNAČAJKAMA RAZVOJA \\ SPLITA U MEĐURATNOM RAZDOBLJU
}

\section{Aleksandar Jakir}

\author{
UDK: 304.3(497.5 Split)“1918/1941“ \\ Pregledni rad
}

Sažetak: Međuratne su godine dio dugotrajnijeg razdoblja općenite modernizacije Splita. Promjene koje je donijela Splitu, nakon što je postao glavnim gradom Dalmacije i glavnom lukom Kraljevine Srba, Hrvata i Slovenaca, bile su duboke i zadirale su u svakodnevni način života i razmišljanja. Split je mijenjao svoj izgled i pretvarao se u moderan grad i dalmatinsko kulturno središte. Električna energija dovedena je u grad 1920. godine, a pet godina nakon toga željeznicom je spojen s unutrašnjosti. Split je u razdoblju između dva svjetska rata udvostručio broj svojih stanovnika i počeo se širiti po dotadašnjim poljima i vinogradima. U gradu su bile otvorene nove škole i počele su djelovati brojne kulturne ustanove. Grad je doživio do tada nezabilježen urbanistički i industrijski razvoj. Malo je vjerojatno da taj nagli razvitak i modernizacija Splita nisu utjecali na mladoga Vladana Desnicu, koji je živio u Splitu od 1920. do 1942. godine, s tim da je njegov odnos prema urbanom prostoru zasigurno prvenstveno bio kulturno određen. Kao prilog raspravi i sustavnijem istraživanju i vrednovanju nekih otvorenih pitanja u vezi s obiteljskim, profesionalnim te, nadasve, generacijskim i umjetničkim sazrijevanjem Vladana Desnice u Splitu, cilj ovoga rada je podsjećanje, u najkraćim crtama, na neke od društvenih i političkih datosti u procesu modernizacije Splita u međuratnom razdoblju u kojemu je Vladan Desnica odrastao i sazrijevao.

Ključne riječi: Split 1918. - 1941., političke i društvene prilike, modernizacija, socijalni miljei

eliki povijesni lom, propast Austro-Ugarske i stvaranje nove jugoslavenske države i za Split je značio početak novog razdoblja u njegovom povijesnom razvoju, obilježenom znatnim promjenama u mnogim sferama života njegovih žitelja. Književnik i kritičar Miljenko Jergović nedavno je uvjerljivo i pomalo sjetno primijetio da svijet o kojemu je Vladan Desnica pripovijedao danas više ne postoji i da ga više nema ni u antropološkom, ni u socijalnom, ni u nacionalnom smislu. ${ }^{1}$ Što je sve određivalo splitsku sredinu u koju je mladi Vladan Desnica došao preseljenjem iz Zadra 1920. godine, kada polazi i završava peti razred klasične gimnazije u Splitu? U razdoblju od samo pedeset godina, između

1 Usp. Miljenko Jergović, „Vladan Desnica. Hitac veselnik. 'Zimsko ljetovanje', roman o dva svijeta koji više ne postoje, zadarskom i srpskom“, Magazin Jutarnjeg lista (Zagreb), 21. i 22. 6. 2014., 65. 
1890. i 1941. godine, broj stanovnika Splita utrostručio se, što je primarno bila posljedica doseljavanja. ${ }^{2}$ Prema prvom popisu nakon Prvoga svjetskog rata 1921., Split je imao 25045 stanovnika, a prema popisu iz 1931. već 35 417. Pretpostavlja se da je 1941. godine u gradu i okolici živjelo već preko 40000 ljudi.

Kao prilog raspravi i sustavnijem istraživanju i vrednovanju nekih otvorenih pitanja u vezi s obiteljskim, profesionalnim te, nadasve, generacijskim i umjetničkim sazrijevanjem Vladana Desnice u Splitu, cilj ovoga rada je podsjećanje, u najkraćim crtama, na neke od društvenih i političkih datosti u procesu modernizacije Splita u međuratnom razdoblju u kojemu je Vladan Desnica odrastao i sazrijevao. Bez mogućnosti da se na ovom mjestu podrobnije bavimo prikazom procesa nestajanja „nesigurnih pripadnosti“ i brisanja „romansko-slavenskoga sinkretizma na istočnoj obali Jadrana“ (Jergović) možemo općenito ustvrditi za međuratno razdoblje u Dalmaciji da su tada dovršena tri, kako su u novijim historiografskim radovima nazvana, nation-building procesa, koji su naposljetku, u manjoj ili većoj mjeri, prihvaćeni u pojedinim zajednicama. Mnoštvo pisanih izvora upućuje na zaključak da su procesi izgradnje hrvatskog, srpskog i talijanskog nacionalnog identiteta dovršeni u drugom desetljeću 20. stoljeća i idu u prilog tezi o afirmaciji modernih nacionalnih identiteta u širokim slojevima društva. A upravo će međuratno razdoblje pokazati da će ilirska/jugoslavenska i slavensko-dalmatinska nacionalna identifikacija, uslijed svojih nedorečenosti, ostati nedovršene mada se u trenutku nastanka modernih nacionalnih programa i identifikacija u Dalmaciji ${ }^{3}$ koncept slavensko-dalmatinskog identiteta u početku čak doimao najuspješnijim u smislu rasprostranjenosti. ${ }^{4}$

Pritom valja imati na umu da je 1880 . godine u Dalmaciji čak $87,4 \%$ stanovništva bilo nepismeno, a taj je postotak 1910. godine još uvijek iznosio 62,91\%..$^{5}$ Možemo pretpostaviti da su stavovi kakve je zagovarao onodobni najveći dnevni list u Splitu, koji svoj naziv Novo doba nije nosio nimalo slučajno ${ }^{6}$ i koji je zdušno zagovarao ujedinjenje svih južnih Slavena, u znatnoj mjeri odražavali duh vremena i mjesta u koje se obitelj Desnica doselila.

2 Usp. Branislav Radica, Novi Split: monografija grada Splita od 1918-1930 godine, Split 1931., 101; Matej ŠKarICA, Splitski shematizam za godinu 1923., Split 1923.; Definitivni rezultati popisa stanovništva od 31. marta 1931. godine, sv. I, Beograd 1937., 9; Ivo Rubić, Gravitacija susjednih žitelja Splita, Zagreb 1930.

3 Usp. Aleksandar JAKIR, „O nekim aspektima procesa oblikovanja nacionalnih identiteta na primjeru Dalmacije između dva svjetska rata", Nacija i nacionalizam u hrvatskoj povijesnoj tradiciji (ur. Tihomir Cipek i Josip Vrandečić), Zagreb 2007., 127-139.

4 Usp. Aleksandar JAKIR, „Dalmacija u procesima stvaranja moderne nacije u 19. i 20. stoljeću“, Spalatumque dedit ortum: zbornik povodom desete godišnjice Odsjeka za povijest Filozofskog fakulteta u Splitu (ur. Ivan Basić i Marko Rimac), Split 2014., 451-477.

5 Usp. navedene izvore i tablice u Aleksandar JAKIR, Dalmatien zwischen den Weltkriegen. Agrarische und urbane Lebenswelt und das Scheitern der jugoslawischen Integration. München 1999., 215-216.

6 Za onodobni tisak usp. Anita Tićinović, Zbirka dalmatinskih novina u Sveučilišnoj knjižnici u Splitu, Split 2004.; Hrvoje Morović, Grada za bibliografiju splitske periodike: novine 1875-1941, Split 1968. Dnevnik Novo doba, koji je pokrenut 9. lipnja 1918., izlazio je tijekom cijelog međuratnog razdoblja. U početnom razdoblju svog izlaženja list je zastupao antiaustrijsku, a projugoslavensku politiku, odnosno ideje Krfske deklaracije, što se može iščitati već u prvom broju iako ih je u početku trebalo uvijeno iznositi. U drugoj polovici listopada godine 1918., u vrijeme raspadanja Austro-Ugarske Monarhije i stvaranja Države SHS list je dosegao nakladu od 7000 primjeraka, što se u ondašnjim prilikama može smatrati izuzetno velikom nakladom. Prvih godina nakon uspostave Kraljevine SHS pripisivala mu se naklonost politici Demokratske stranke, što ni uredništvo lista nije skrivalo, ali se ipak odlučilo za uređivanje lista neovisno od stranačkih utjecaja. Prvo razdoblje njegovog djelovanja obilježeno je i suprotstavljanjem talijanskim pretenzijama na istočnu obalu Jadrana. Usp. Zdravka Jelaska Marijan, Grad i ljudi: Split 1918.-1941., Zagreb 2009., 460-462; Branka BoвAN, „Dalmacija između jugoslavenstva i hrvatstva 1920.-1923. godine (u svjetlu splitskog dnevnika Novo Doba)“, Dijalog povjesničara - istoričara, knj. 4 (ur. Hans-Georg Fleck i Igor Graovac), Zagreb 2003., 127-145. 
Povijesna je činjenica da je u dalmatinskim gradovima koncem listopada i početkom studenoga 1918. dolazilo do prosvjednih skupova i demonstracija na kojima se iskazivalo oduševljenje mogućnošću južnoslavenskog ujedinjenja. Već od srpnja 1918., usprkos ratnom stanju, u Splitu i okolnim mjestima zabilježene su sve učestalije manifestacije na kojima se podržavala ideja stvaranja južnoslavenske države. Prijenos vlasti na novostvorenu Državu SHS i stvarna tranzicija nakon raspada Austro-Ugarske u studenom 1918. godine prošle su glatko i mirno.7 Čini se nespornim da je kraj Austro-Ugarske 1918. godine u Splitu kao i u cijeloj Dalmaciji, nakon više od sto godina života u Habsburškoj Monarhiji, dočekan s velikim odobravanjem. Mogli bismo općenito reći da su se tradicionalne strukture moći u južnoslavenskim pokrajinama Austro-Ugarske još prije kraja Prvoga svjetskog rata počele raspadati. No, očigledno je da je do oblikovanja političkog pokreta i unitarističkoga nacionalnog koncepta u Dalmaciji po prvi puta došlo tek pod uvjetima masovne mobilizacije širokih društvenih slojeva kakvu je i u perifernoj i siromašnoj austrijskoj pokrajini na istočnoj obali Jadrana prouzročio do tada najveći i najstrašniji rat, kasnije nazvan Prvim svjetskim ratom, u kojemu je, prema nekim procjenama, i 34000 Dalmatinaca izgubilo živote.

Veliki rat, kako su ga suvremenici zvali, bio je globalni sukob s posljedicama za čitav svijet. U potpunosti je promijenio političku i socijalnu sliku Europe i njezinih kolonija te je navijestio nove omjere snaga i sukobe. Ta strašna ljudska klaonica, u kojoj su milijuni ljudi izgubili život, ${ }^{8}$ izazvala je do tada nezamislivu materijalnu štetu na područjima izravno zahvaćenima ratom, ali i privredni kolaps pozadine. U tom ratu propala su četiri carstva i iz njih su nastale nove države, a njegov ishod presudno je usmjerio politička zbivanja nakon njegovog završetka. Novija istraživanja, kao što je studija Filipa Škiljana o Prvom svjetskom ratu u Dalmaciji, pokazuju kolike su bile glad i neishranjenost upravo u ovoj slaborodnoj a - gledajući obradivu agrarnu površinu - gusto naseljenoj regiji. U novijoj literaturi možemo naći procjene o nekih 137000 vojnika iz hrvatskih krajeva stradalih na raznim bojištima. Još oko 109000 ljudi, uglavnom civila, umrlo je od raznih epidemija i gladi. Postupno, kako je rat trajao, i nepismeni su se vojnici počeli pitati o smislu rata. Imamo dosta svjedočanstava o tome da je prema početku 1918. sve više dolazilo do zamora i to ne samo među vojnicima. Tako na primjer istraživanja Filipa Hameršaka, koji je analizirao mnoge autobiografije časnika, pripadnika generacija rođenih nakon 1870. godine, pokazuju da su se sve više počinjali preispitivati predmoderni pojmovi osobne časti, odanosti vladaru, borbe za junaštvo i njima slični. Zasigurno nisu samo pisci tih autobiografija bili dobrim dijelom određeni svojim ratnim iskustvom. ${ }^{9}$ Najveća dalmatinska grobnica u Prvom svjetskom ratu bila je na Sočanskoj bojišnici. Kao što je s pravom primijećeno, Dalmatinci koji su izginuli na Soči nisu imali svojega Krležu, svojega Hašeka ili svojega Remarquea da to stradanje u kolektivnoj memoriji ostavi dubljeg traga o njihovoj žrtvi, o njihovim uzaludnim smrtima i još uzaludnijim pobjedama. ${ }^{10} \mathrm{~S}$ druge strane, nakon 1918., nisu imali ni aureolu pobjed-

\footnotetext{
Usp. A. JaKIR, Dalmatien zwischen den Weltkriegen, 83-90.

8 Usp. bibliografiju radova kojoj se može pristupiti preko poveznice https://en.wikipedia.org/wiki/Bibliography_of_ World_War_I. Za posebni fokus na prilike u Dalmaciji usp. Ante BraLIć, Zadar u Prvom sujetskom ratu, doktorska disertacija, Zadar 2006.; Filip ŠKILJAN, Prvi svjetski rat u Dalmaciji (1914. - 1918.), Split - Dubrovnik 2014.

9 Usp. Filip НамеRšAK, Tamna povijest rata. Hrvatska autobiografija i Prvi svjetski rat, Zagreb 2013.

10 Usp. Davor Krile, „Sočanska bojišnica - najveće dalmatinsko groblje“, Slobodna Dalmacija (Split), 12. 4. 2014., $16-17$.
} 
nika da bi preživjeli slobodno mogli pričati o svojim ratnim uspomenama. Kosti nebrojenih otočana, primoraca i onih koji su došli iz nekog mjesta Dalmatinske zagore zauvijek su ostali na hrptovima Alpa. Ukupno je na Sočanskoj bojišnici, procjenjuje se, u Prvom svjetskom ratu izginulo oko milijun ljudi. Zasigurno su rat i poraće ostavili snažan trag u svijesti suvremenika.

U splitskoj kronologiji Vladana Desnice nailazimo na podatak da završetak rata „za porodicu Desnica nije značio i prestanak ratnih i poratnih briga te početak normaliziranja života, nego čak i pogoršanje uvjeta života“. Vladan Desnica prelazi iz Zadra u Split, „kao što će to učiniti gotovo svi iz njegove generacije ne želeći pohađati daljnje školovanje na talijanskom jeziku koji se ponovno uvodi u škole po uspostavljanju talijanske vlasti u Zadru“. ${ }^{11}$ On prelazi u grad u kojemu je njegov otac politički aktivan već od vremena sutona Dvojne Monarhije. Kao dobar primjer možemo navesti veliki Narodni zbor u Splitu 2. srpnja 1918., na kojemu su sudjelovali istaknuti članovi i pristalice predratnih političkih stranaka iz svih krajeva Dalmacije, a unaprijed pripremljena i jednoglasno prihvaćena politička rezolucija - Splitska rezolucija - koja je izglasana na spomenutom Narodnom zboru ukazuje na konsenzus među glavnim političkim snagama u tom trenutku oko stvaranja zajedničke južnoslavenske države putem samoodređenja, zamišljene kao država etnički jedinstvenog „troimenog“ slovensko-srpsko-hrvatskog naroda. Ako je vjerovati onodobnom tisku, političku rezoluciju podržavalo je „svekoliko pučanstvo dalmatinsko“. U skladu s tim u Dalmaciji više i nije došlo do obnavljanja predratnih političkih stranaka, već do koncentracije političkih snaga radi stvaranja Narodnog vijeća. Na zboru je izabrana uprava $\mathrm{Na}-$ rodne organizacije Srba, Hrvata i Slovenaca koju su, između ostalih, činili Gajo Bulat, Ivo Krstelj, Ivan Majstrović i Dujam Mikačić te otac Vladana Desnice, Uroš Desnica. Svi oni će kasnije imati važne uloge u djelovanju političkih stranaka u Splitu. Na skupu su izglasane i gospodarske rezolucije u kojima su se iznijeli brojni prijedlozi za poboljšanje teškog gospodarskog stanja Dalmacije. U istom duhu kao i Splitska rezolucija u Zagrebu je 19. listopada 1918. izglasana Deklaracija Narodnog vijeća SHS, kojom je zatraženo „ujedinjenje cjelokupnog našeg naroda Slovenaca, Hrvata i Srba na čitavom njegovom etnografskom teritoriju, bez obzira na pokrajinske ili državne granice u kojima danas žive - u jednu jedinstvenu potpuno suverenu državu, na načelima političke i ekonomske demokracije“. Narodno vijeće Srba, Hrvata i Slovenaca postalo je, dopuštenjem svih stranaka, jedini predstavnik naroda, ${ }^{12}$ što je značilo da s pravom možemo pretpostaviti da je tada u jugoslavenski orijentiranoj dalmatinskoj javnosti i Uroš Desnica uživao veliki ugled zbog svoje istaknute uloge u tim zbivanjima. Zaključke Narodnog vijeća donesene 17. - 19. listopada 1918., kao i Deklaraciju od 19. listopada, objavio je splitski dnevnik Novo doba na prvoj stranici svoga

11 Dušan Marinković, „Biografija Vladana Desnice“, Hotimično iskustvo: diskurzivna proza Vladana Desnice. Knjiga druga (prir. Dušan Marinković), Zagreb 2006., 223.

12 Usp. Dragovan ŠepIĆ, Italija, saveznici i jugoslavensko pitanje, Zagreb 1970., 365; Bogdan Krizman, Raspad AustroUgarske i stvaranje jugoslavenske države, Zagreb 1977., 58-60; Ljubo BoвAN, „Kada je i kako nastala Država Slovenaca, Hrvata i Srba“, Časopis za suvremenu povijest, 24/1992., br. 3, 48-49; Hodimir Sirot ković, „O nastanku, organizaciji, državnopravnim pitanjima i sukcesiji Države SHS nastale u jesen 1918.“, Časopis za suvremenu povijest, 24/1992., br. 3, 61-65. 
broja od 24. listopada 1918. godine. Odluka da je Narodno vijeće od tog trenutka jedini predstavnik naroda bila je posebno naglašena.

Sva ta politička zbivanja događala su se u kontekstu izrazito loše ekonomske situacije u Splitu i Dalmaciji. Splitski su težaci još tijekom ljeta bili pozvani da žito dobrovoljno predaju tzv. Gradskoj aprovizaciji, a u listopadu je gradom počela harati španjolska gripa. ${ }^{13}$ Središnje Narodno vijeće osnovano je početkom listopada 1918. u Zagrebu, a u njegov su Plenum iz Dalmacije ušli Mate Drinković, Gajo Bulat, Ivo Krstelj, Prvislav Grisogono, Stanko Banić, Milan Marušić i Uroš Desnica. ${ }^{14}$

Otac Vladana Desnice, Uroš, kao i njegov djed Vladimir, dugogodišnji načelnik Obrovca, zalagali su se za hrvatsko-srpsku koaliciju pa ih je austrijska strana smatrala veleizdajnicima već i znatno prije početka rata 1914. godine. S druge strane, nakon sloma AustroUgarske, obitelj Desnica bila je, dakako, među javno uvažavanim „prvoborcima“ za novu jugoslavensku nacionalnu državu pod narodnom dinastijom. Uroš Desnica bio je čelni čovjek zadarskoga Narodnog vijeća, a istovremeno je bio i u vrhu Narodnog vijeća Dalmacije, potpredsjednik zemaljske vlade Dalmacije i povjerenik za pravosuđe. Upravo to ga je kasnije stajalo internacije u Italiji 1919./20., a ubrzo potom i gubitka imovine u Zadru i obustave rada odvjetničkog ureda. Kao što je Drago Roksandić ustvrdio, u konačnici je zbog toga obitelj Desnica i došla u Split. ${ }^{15}$

U Splitu je prekid državotvornih veza s Austro-Ugarskom dočekan s oduševljenjem, a Uprava Narodne organizacije za Dalmaciju potpuno je nesmetano preuzela vlast. Onodobni tisak ističe da je masa ljudi izašla na gradske ulice i klicala u čast Jugoslavije, Trumbića i Wilsona. ${ }^{16}$ Poznata je i uzrečica urednika Novoga doba Vinka Kisića da je atmosfera u Dalmaciji uoči i nakon propasti Austro-Ugarske Monarhije odavala „sredinu kolektivnog ludila“. Gledano iz današnje perspektive, s povijesnim odmakom i nakon što su propale dvije jugoslavenske države u 20. stoljeću, jasnije se, naravno, vidi da su stavovi kakvi su izrečeni na onodobnom skupu u Splitu pred kraj Prvog svjetskog rata bili uvjetovani ondašnjom teškom gospodarskom situacijom i strahom od talijanskih pretenzija na istočnu obalu Jadrana. ${ }^{17}$

Upravu Splitske općine od austrijskog komesara preuzeo je „privremeni općinski odbor“, sastavljen od preživjelih članova Općinskoga vijeća izabranog na posljednjim prijeratnim općinskim izborima godine 1913. Za novog je gradonačelnika, zbog smrti Vinka Katalinića, imenovan Josip Smodlaka. No, Smodlaka se svoga mjesta odrekao nakon tjedan dana, zbog svoje nove funkcije, pa je na sjednici održanoj tjedan dana poslije za novog gradonačelnika

13 Usp. Marijan Buljan, Političke stranke u Splitu od 1918. do 1929., diplomski rad, Split 2011.

14 Z. Jelaska Marijan, Grad i ljudi, 68.

15 Usp. Drago Roksandić, „Dr. Uroš Desnica 1918. - 1921.: životopisne nedoumice na raskrižju epoha“, Spalatumque dedit ortum: zbornik povodom desete godišnjice Odsjeka za povijest Filozofskog fakulteta u Splitu (ur. Ivan Basić i Marko Rimac), Split 2014., 506.

16 B. Radica, Novi Split, 12-13; „Preporučamo mir i red“i „Velike narodne manifestacije u Splitu“, Novo doba (Split), br. 142, 29. 10. 1918., 3; „Split za Jugoslaviju: Veličanstvena narodna manifestacija“, Novo doba (Split), br. $143,30$. 10. 1918., 1; Z. Jelaska Marijan, Grad i ljudi, 69-70; M. Buljan, Političke stranke u Splitu, 6.

17 Usp. A. Jakir, Dalmatien zwischen den Weltkriegen, 94-106; Ivo John Lederer, Yugoslavia at the Paris Peace Conference. A Study in Frontier Making, New Haven - London 1963. i B. Krizman, Raspad Austro-Ugarske. 


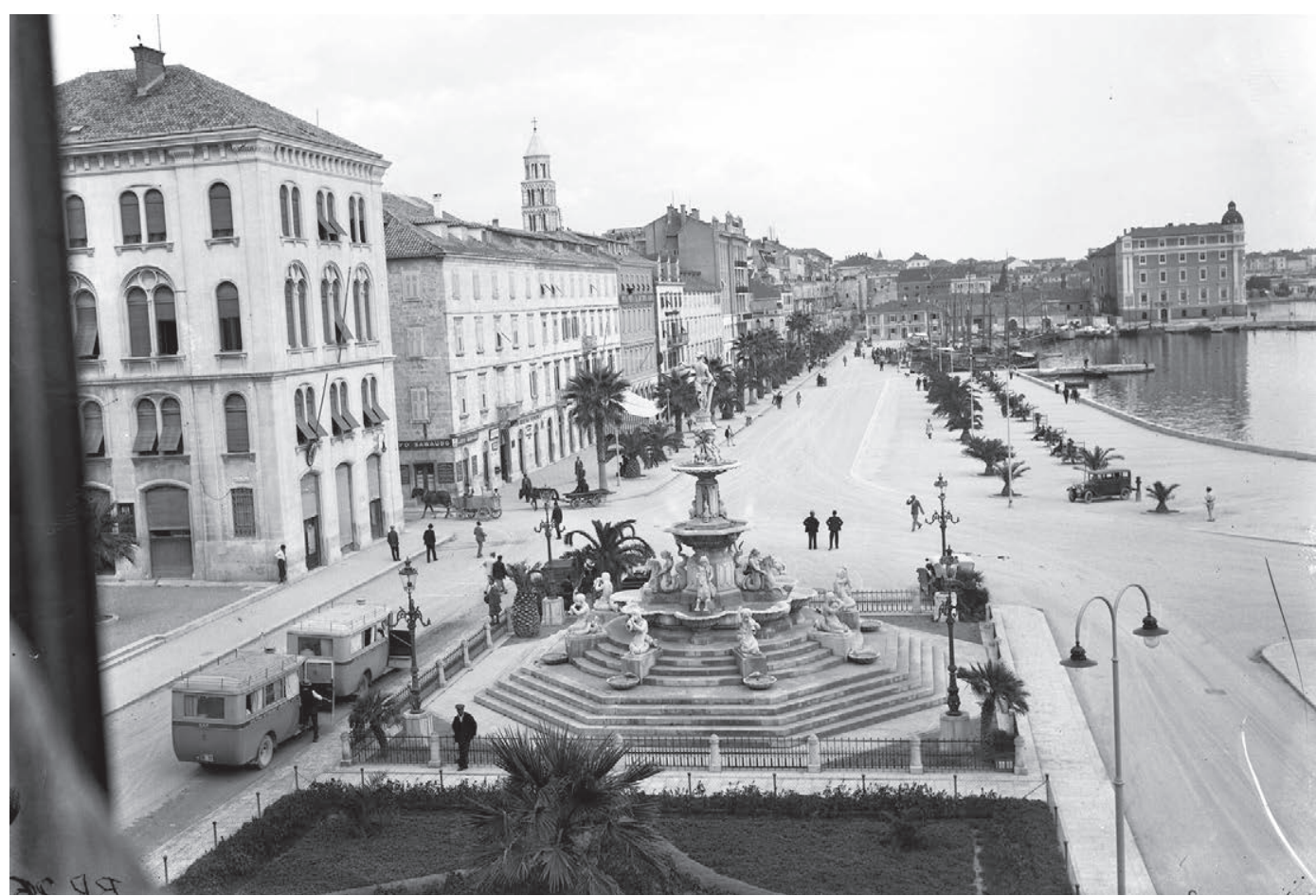

Sl. 1. Splitska riva oko 1928. godine

jednoglasno izabran Ivo Tartaglia, koji će tu dužnost vršiti gotovo deset godina. ${ }^{18}$ Stvorena je i „Zemaljska vlada za Dalmaciju“ u Splitu, najvjerojatnije prema naredbi Narodnog vijeća SHS u Zagrebu, na čelu s Krsteljom, Škaricom i Smodlakom. Potonji je na sjednicama Središnjega odbora Narodnoga vijeća zagovarao što brže ujedinjenje sa Srbijom. ${ }^{19}$

Split u prvih desetak godina prve Jugoslavije pamti jedno vrlo dinamično razdoblje svoje novije povijesti i bilježi krupne društtvene promjene. ${ }^{20}$ Bio je to grad u kojemu je radilo šest tiskara i u kojemu su izlazile brojne novine. U razdoblju od 1918. do 1929. tiskano je oko sedamdeset naslova raznih novina, od raznih političkih glasila preko književnih časopisa, poput Korablje Ćire Čičin-Šaina, do kolopleta humorističkih listova. Godine 1920. Split je dobio električnu rasvjetu, a 1923. je započela značajnija elektrifikacija grada. Tijekom 1920-ih pošumljavan je Marjan. Nije pretjerano reći da je Split doživio značajan urbanistički i prosvjetni procvat. Generalni urbanistički plan odredio je glavne smjernice razvoja,

18 Usp. Norka Machiedo Mladinić, „Životni put dr. Ive Tartaglie. Split, 6. II. 1880. - Lepoglava, 3. IV. 1949.“, $R a-$ dovi zavoda za hrvatsku povijest, 26/1993., 281-288; Norka Machiedo MLadinić, „Oskar Tartaglia: od jugoslavenskog nacionalista do žrtve komunističke represije“, Časopis za suvremenu povijest, 35/2003., br. 3., 903-920.

19 „Privremeni općinski odbor“, Novo doba (Split), br. 144, 31. 10. 1918., 4; „Općinski odbor“, Novo doba (Split), br. 151, 7. 11. 1918., 6; B. Radica, Novi Split, 14-15, 69-71; Josip SmodlaKa, Zapisi dra Josipa Smodlake (ur. Marko Kostrenčić), Zagreb 1972., 74-75; Z. Jelaska Marijan, Grad i ljudi, 71-75, 89-90. Više o Zemaljskoj vladi za Dalmaciju vidi u Zdravka Jelaska Marijan, „Zemaljska vlada za Dalmaciju (2. studenoga 1918. - 20. siječnja 1919.), Godina 1918: prethodnice, zbivanja, posljedice. Zbornik radova s medunarodnoga znanstvenog skupa (ur. Zlatko Matijević), Zagreb 2010., 155-170.

20 Usp. A. Jakir, Dalmatien zwischen den Weltkriegen, 239-262; Stanko Piplović, Izgradnja Splita između svjetskih ratova, Split 2008. 
a Split je stekao titulu najveće državne luke novostvorene Kraljevine Srba, Hrvata i Slovenaca. Poseban utjecaj na razvoj Splita imao je dugogodišnji gradonačelnik (između 1918. i 1928. godine) i kasniji ban Primorske banovine Ivo Tartaglia. ${ }^{21}$

Dakako, gospodarski rast nipošto nije značio da nije bilo ozbiljnih društvenih antagonizama u gradu. U obzir se mora uzeti i način života u selima koja su gravitirala prema Splitu. Općenito loša prilagodba dalmatinskoga sela, $s$ uglavnom nedovoljno učinkovitom i nerentabilnom poljoprivredom te, općenito uzevši, dalmatinsko gospodarstvo koje nije bilo u stanju pratiti modernizacijski tempo kapitalističkih ekonomija, ukazuju na problem (ako ga uspoređujemo s europskim prosjekom tog vremena) nedovoljne produktivnosti rada, manjka kapitala i nepostojanja razvijenoga tržišta za njegove proizvode, što je rezultiralo sveopćim siromaštvom, koje je u Dalmatinskoj zagori poprimalo dramatične razmjere.

Očekivanja su nakon Prvoga svjetskog rata bila velika. Postojala je nada da će se teški ekonomski položaj velike većine dalmatinskoga stanovništva unutar jugoslavenske države popraviti. No, analiza pisanja ondašnjega tiska upućuje na razočaranost brzinom i razmjerima industrijalizacije. Isto vrijedi i za neuspjeh agrarne reforme i općenito teške gospodarske prilike. To su bile dominantne značajke stanja dalmatinskoga sela, a čija je statičnost utjecala na spori ritam modernizacije. ${ }^{22}$

Međutim, nedvojbeno je međuratno razdoblje, na planu društvenog razvoja, dio dugotrajnijega razdoblja opće modernizacije. Elektrifikacija, ${ }^{23}$ izgradnja gradske infrastrukture, novih prometnica i željezničkih pruga te porast lučkog prometa nesumnjivo su bili temelji gospodarskog napretka Splita. Najrazvijenija industrijska grana na širem splitskom području nakon Prvoga svjetskog rata bila je cementna industrija (uz one u gradu sa tvornicama u Solinu i Kaštel Sućurcu). Slijedile su brodogradnja, prehrambena industrija, industrija bezalkoholnih i alkoholnih pića. Industrijalizacija Dalmacije dobila je prvi zamah, bez kojeg „ekonomski napredak“ ne bi bio moguć, ${ }^{24}$ mada iz statistike industrije Kraljevine Jugoslavije proizlazi da se i nakon dvadeset godina u Dalmaciji nije nalazilo više od 3,8\% svih industrijskih pogona u državi. ${ }^{25}$

U seriji članaka u Novom dobu početkom 1920-ih godina neki autori - primjerice Marcel Martinis i Marko Car - naglašavaju da je Split grad koji „živi za budućnost“, grad koji

21 Usp. Aleksandar JAKIR - Marijan BulJaN (ur.), Ivo Tartaglia, političar i intelektualac. Zbornik radova sa znanstvenog skupa 23. i 24. rujna 2013., Split 2015.

22 Usp. A. Jakir, Dalmatien zwischen den Weltkriegen, 130-238; Zdenka Šıмоnčić-Boвetко, Agrarna reforma i kolonizacija u Hrvatskoj 1918.-1941., Zagreb 1997. і Stijepo Oвар, Dalmatinsko selo u prošlosti, Split 1990. Ovdje bih samo naveo jedan gospodarski pokazatelj: Dalmacija, koja je bila slabo razvijena pokrajina Austro-Ugarske, u Kraljevini SHS 1923. g. imala je dohodak po stanovniku od 2831 dinara. Istodobno su Hrvatska i Slavonija imale 3681 dinara, a Slovenija je bila najrazvijenija s više od 4000 dinara dohotka po stanovniku. Pored statističkih izvora koje navodim u svojoj monografiji, još uvijek mi se, uglavnom, za to razdoblje čine pouzdanim podatci koje donosi Mijo Mirković. Usp. Mijo Mirković, Ekonomska struktura Jugoslavije 1918-1941, Zagreb 1950. ili Mijo Mirković, Ekonomska historija Jugoslavije, Zagreb 1962.

23 Usp. Petar Jutronıć, „Prikaz elektrifikacije Dalmacije i energetska situacija“, Zbornik Društva inženjera i tehničara u Splitu (ur. Slavko Sirišćević), Split 1958., 441-466.

24 Ivo Belin, „Oblasne takse i industrijalizacija Dalmacije“, Novo doba (Split), br. 10, 13. 1. 1928., 3.

25 Usp. Statistika industrije Kraljevine Jugoslavije, sa adresarom industriskih preduzeća, Beograd 1941., 72; Stevan KuкоLEČA, Industrija Jugoslavije 1918-1938, Beograd 1941., 74-165; Smiljana Đurović, „Pregled literature o industrijalizaciji jugoslovenskih zemalja u periodu 1918-1941. g.“, Istorijski glasnik, br. 1-2/1967., 155-191. Za 1938. godinu nailazimo na podatak od 70 tvornica u Dalmaciji s 5826 radnika. 


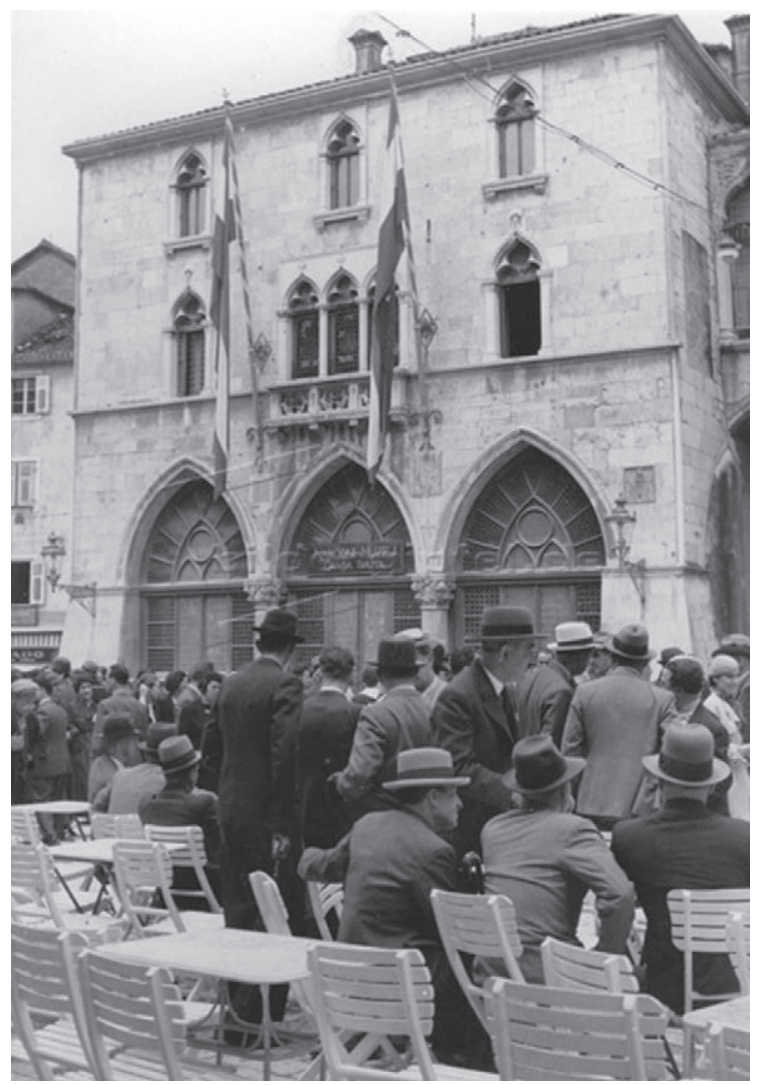

Sl. 2. Između gradske kavane i stare gradske vijećnice 1930-ih

namjerava zauzeti mjesto trećeg kulturnog i ekonomskog centra u državi (nakon Beograda i Zagreba), ${ }^{26}$ a „,Split koji iščezava“ je onaj s „kućaricama na obali", koje se od dima iz dimnjaka tvornica više ne vide. ${ }^{27}$ Mnogima se činilo da je jedino potrebno prevladati „izoliranost“ Splita i cijele obale „od ostalog svijeta i našeg velikog nacionalnog zaleđa" kako bi Split doživio neviđeni procvat na svim poljima. ${ }^{28}$

Na polju svakodnevnog života, koji se mijenjao, promjene nakon Prvoga svjetskog rata i „lude splitske godine“ lijepo su opisane. ${ }^{29}$ Znakovi modernizacije su pored ostalog i automobili, uvođenje autobusnog prijevoza, elektrifikacija grada, grijanje u stanovima i dr., a vidjeli su se i u ženskoj modi. Žene su počele skraćivati kosu, a skraćivala se i suknja. Zdravka Jelaska Marijan u svojoj monografiji govori o tome gdje su izlazili, gdje su se sastajali i kako su se zabavljali. Najznačajnija mjesta za izlazak Splićana bili su Pjaca i Riva, gdje su građani provodili sate u razgovorima i prepričavanju dnevnih događaja. Pjaca je bila središte formalnoga i neformalnoga javnog života. Bilo je to glavno mjesto večernjih šetnji i izlazaka, mjesto na kojem je smještena glavna gradska kavana, kao i Općinska uprava. Za razliku od Pjace splitska Riva je bila središte gospodarskog života. Na Rivi su se nizale različite trgovine, poslovnice banaka, ali i kavane. U kavanama, gostionicama, konobama i brijačnicama događao se društveni život. Takva mjesta su posjećivali političari, umjetnici i studenti, a služila su za ugodna druženja i razmjenu informacija. U kavanama, gostionicama i brijačnicama nalazile su se novine čiji su se članci i događaji komentirali. Brijačnice su bile namijenjene isključivo muškarcima, a u njima se često vodio živi razgovor, komentirali politički događaji, lokalne teme i sportski događaji. Prema podatcima koje iznosi Zdravka Jelaska Marijan, Split je imao 13 kavana, 80 gostionica, 61 buffet, 31 krčmu i sedam točionica vina.

U dodir s kulturnim sadržajima Splićani su dolazili prije svega u kazalištima i kinima, središtima kulturnog života. U rujnu 1921. počelo je djelovati prvo profesionalno kazalište

\footnotetext{
26 Usp. Marko CAR, „Utisci iz Splita“, Novo doba (Split), br. 182, 12. 8. 1922., 2-3.

27 Ivo Delalle, „Split koji iščezava. Kućarice na obali“, Novo doba (Split), br. 89, 15. 4. 1924., 2.

28 Usp. Krunoslav Bego, Grad Split i njegova općina, Beograd 1927.

29 Usp. Anatolij KudrJavcev, Vječni Split, Split 1985.
} 


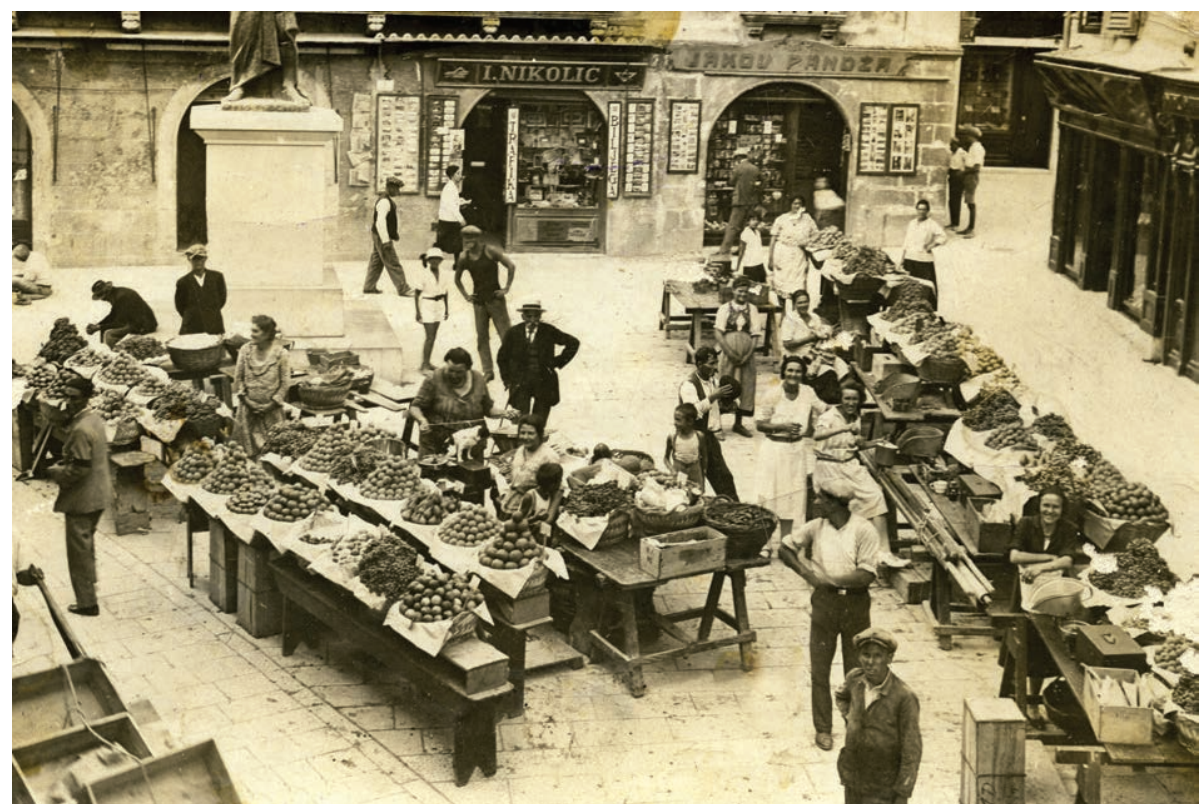

\section{Sl. 3. Voćni trg sredinom 1930-ih}

pod nazivom Narodno pozorište za Dalmaciju. Osim kazališta, popularno mjesto za mlade bila su i kina. U međuratnom razdoblju u Splitu su bila četiri kina: „Karaman“ („Elektrobioskop“), „Eden“, „Tesla“ i „Central“. Sliku Splita uljepšavale su i splitske česme, koje su nekada opskrbljivale građane pitkom vodom. Česme i tržnice, kojih je tada bilo pet, dopunjavale su društveni život Splićana jer se na tim mjestima uvijek moglo popričati sa susjedom ili poznanikom. U ljetnim mjesecima i danas je najomiljenije mjesto javnoga života građana Splita kupalište Bačvice. Otvoreno je 18. svibnja 1919., a za kupanje su se naplaćivale ulaznice. $\mathrm{Na}$ Bačvicama su najviše uživala djeca, ali i stariji igrajući picigin u plićaku. „Kulturnom i umjetničkom životu grada“ pečat su dale knjižnice, muzeji, i galerije. Kao što je poznato, u međuratnom Splitu su trajno ili privremeno djelovali mnogi umjetnici, među kojima slikari Emanuel Vidović, Anđeo Uvodić, Antun Zuppa, Vjekoslav Parać i Jozo Kljaković, slikar i književnik Ante Katunarić, kipari Ivan Meštrović, Tomo Rosandić i Marin Studin, književnici Ante Tresić Pavičić, Tin Ujević, Marin Bego, Marko Uvodić, Ante Cettineo, Rikard Katalinić Jeretov, Vladimir Čerina, Dinko Šimunović, Ante Petravić, Niko Bartulović, Lora Klier, Vera Škurla Ilić i Bogdan Radica, glazbenici Josip Hatze, Ivo Tijardović i drugi. Split je nedvojbeno bio kulturno središte Dalmacije, čiji su umjetnici svojim radom obilježili cijelo razdoblje prve jugoslavenske države. ${ }^{30}$

Za međuratno razdoblje možemo zasigurno reći da je Split krenuo velikim koracima prema suvremenijoj budućnosti. Privatni i javni život svih društvenih slojeva Splićana (građana, težaka i radnika) dobivao je nova obličja u gradu koji se sve brže mijenjao. Grad se razvijao na svim područjima, a demografski i gospodarski razvoj temeljne su smjernice sveopćeg razvoja - tehnološkog, kulturnog, društvenog i gospodarskog. Ubrzani priljev

30 Usp. Joško Barić - Šimun Jurišrć, Splitsko iverje 1882-1941 (Iz povijesti Splita), Split 1983. 
stanovništva i nastajanje novih gradskih četvrti u rubnim dijelovima grada nametali su potrebu osiguravanja primjerene gradske infrastrukture, prvenstveno elektrifikacije, vodovoda i kanalizacije.

U svakodnevnici Splita u međuratnom razdoblju ispreplitali su se kulturno-gospodarski napredak i tradicija. Svakodnevni život Splićana može se sagledavati kroz odnose unutar obitelji i kroz unutardruštvene odnose, kroz tradiciju i običaje, kroz obrazovanje, modu, kulturni i javni život te kroz stanovanje. Sve je to uglavnom ovisilo o materijalnom i društvenom statusu.

Prema popisu iz 1931. na području kotara Split bilo je 40,9\% nepismenih. Pretpostavlja se da je u samom gradu većina stanovnika bila pismena, a nepismenih je bilo više zbog masovnog doseljavanja stanovnika iz Dalmatinske zagore. ${ }^{31}$ Krajem Prvoga svjetskog rata u Splitu su djelovale tri gimnazije, četiri strukovne škole i jedna građanska, a u međuratnom razdoblju otvorena je još jedna gimnazija i jedna građanska škola. Državna klasična gimnazija, nasljednica gimnazije koju je još 1700. osnovao nadbiskup Stjepan Cosmi i koju je 1817. preuzela država, nakon Prvog svjetskog rata bila je u staroj državnoj zgradi u Nodilovoj $5 .{ }^{32} \mathrm{Nju}$ je pohađao i Vladan Desnica.

Premda je u međuratnom Splitu bilo sve više gospodarskih i društveno-kulturnih promjena usmjerenih poboljšavanju sveopćeg društvenog i životnog okruženja, još su uvijek bili prisutni i mnogi elementi tradicije, koji se najlakše mogu uočiti na primjeru splitskih težaka koji nisu gledali blagonaklono na nove izume poput gramofona, telefona, radija ili automobila. No, svjetska tehnološka dostignuća dvadesetog stoljeća sve više su osvajala Split i zadirući u svaki segment života izravno utjecala na svakodnevnicu i na društveni život Splićana. Temeljni koraci ka modernizaciji grada osmišljeni su u rješavanju vitalne gradske infrastrukture. Uvođenjem elektrifikacije, izgradnjom vodovodne mreže, rješavanjem problema kanalizacije i smeća, proširivanjem i izgradnjom prometnica (cesta, željeznice, pomorskih luka) nakon Prvoga svjetskog rata grad dobiva drugačiju i bolju dimenziju koja mu otvara velika vrata prema suvremenijoj budućnosti. Split postaje veliko gradilište u koje se slijeva sve veći broj stanovnika iz okolice u potrazi za poslom. Split postaje najznačajniji grad i luka primorskog dijela Hrvatske unutar jugoslavenske države.

Osim demografskog, gospodarskog i prostornog širenja, Split doživljava i kulturološke promjene. Stapajući se s tradicijom, one ovom gradu i njegovim stanovnicima daju osobit identitet.

Već ovih nekoliko natuknica o nekim aspektima modernizacije života grada koja je obilježila Split u međuratnom razdoblju ukazuju na činjenicu da je Vladan Desnica odrastao i sazrijevao u gradu koji je u međuratnom razdoblju bio zahvaćen značajnim promjenama koje su utrle put razvoju malog mediteranskog gradića u moderan lučki i industrijalizirani grad.

31 Z. Jelaska Marijan, Grad i ljudi, 298.

32 Isto, 309. 


\section{$\cos$}

\section{Certain Characteristics of the Development of SPlit in the Interwar Period}

Interwar Split experienced a major shift in its urban and educational qualities. The general urban plan set the main guidelines of development, and Split became the largest port in the newly-created Kingdom of Serbs, Croats and Slovenes. The interwar period is part of a more long term modernisation process, and it brought Split, the capital of Dalmatia, deep and thorough modifications in everyday life and thinking. The city of Split changed its appearance and became a modern city and the cultural centre of the Dalmatian coast. In 1920 electricity was brought in, and five years after this fact, the railroad with the interior was completed. Split's population doubled between the wars and it spread along the fields and vineyards in the town's surroundings. New schools and many cultural institutions began functioning. An unprecedented level of urbanistic and industrial development was leashed upon the city. It is highly unlikely that the sudden development and modernisation of Split bypassed the young Vladan Desnica, who lived in the city from 1920 to 1942, considering that his relationship with his surroundings was culturally determined. Contributing to the debate and a more systematic research of some open questions regarding the familial, professional, generational and artistic development of Vladan Desnica, this paper aims to recount, in the briefest possible terms, some of the social and political instances in the modernisation of Split in the interwar era during which Vladan Desnica grew up. Economic growth did not preclude serious social antagonism in the city, especially when we see the way of life in the villages gravitating towards Split. After the First World War expectations were high that the severe economic status of most of the Dalmatian populace would recover in the Yugoslav state. However, an analysis of the contemporary media points to the disappointment with the speed and breadth of industrialisation. The same holds for the failure of the agrarian reform and general poor economic circumstances as characteristics in the Dalmatian countryside, that was static up to the point of slowing the rhythm of modernisation. But, electrification, construction of urban infrastructure, new roads and railways, the increase in shipping, etc., undoubtedly formed the basis for economic growth in this time. A series of articles in the Split daily Novo doba written by Marcel Martinis and Marko Car during the early 1920s emphasize the fact that Split was a city "living for the future", a city that planned to become the third cultural and economic center in the state (after Belgrade and Zagreb).

Keywords: Split 1918-1941, political and social events, modernization, social milieus

\section{$\cos$}

\section{Literatura}

Joško Barić - Šimun Jurišıć, Splitsko iverje 1882-1941 (Iz povijesti Splita), Split 1983.

Krunoslav Bego, Grad Split i njegova općina, Beograd 1927.

Ivo Belin, „Oblasne takse i industrijalizacija Dalmacije“, Novo doba (Split), br. 10, 13. 1. 1928., 3.

Branka BoBAN, „Dalmacija između jugoslavenstva i hrvatstva 1920.-1923. godine (u svjetlu splitskog dnevnika Novo Doba)“, Dijalog povjesničara - istoričara, knj. 4 (ur. Hans-Georg Fleck i Igor Graovac), Zagreb 2003., 127-145. 
Ljubo Boban, „Kada je i kako nastala Država Slovenaca, Hrvata i Srba“, Časopis za suvremenu povijest, 24/1992., br. 3, 45-60.

Ante Bralić, Zadar u Prvom svjetskom ratu, doktorska disertacija, Zadar 2006.

Marijan Buljan, Političke stranke u Splitu od 1918. do 1929., diplomski rad, Split 2011.

Definitivni rezultati popisa stanovništva od 31. marta 1931. godine, sv. I, Beograd 1937.

Marko CAR, „Utisci iz Splita“, Novo doba (Split), br. 182, 12. 8. 1922., 2-3.

Ivo Delalle, „Split koji iščezava. Kućarice na obali“, Novo doba (Split), br. 89, 15. 4. 1924., 2.

Smiljana Đurović, „Pregled literature o industrijalizaciji jugoslovenskih zemalja u periodu 19181941. g.“, Istorijski glasnik, br. 1-2/1967., 155-191.

Filip HameršAn, Tamna povijest rata. Hrvatska autobiografija i Prvi svjetski rat, Zagreb 2013.

Aleksandar JAKIR, „Dalmacija u procesima stvaranja moderne nacije u 19. i 20. stoljeću“, Spalatumque dedit ortum: zbornik povodom desete godišnjice Odsjeka za povijest Filozofskog fakulteta u Splitu (ur. Ivan Basić i Marko Rimac), Split 2014., 451-477.

Aleksandar JAKIR, Dalmatien zwischen den Weltkriegen. Agrarische und urbane Lebenswelt und das Scheitern der jugoslawischen Integration. München 1999.

Aleksandar JAKIR - Marijan BulJAN (ur.), Ivo Tartaglia, političar i intelektualac. Zbornik radova sa znanstvenog skupa 23. i 24. rujna 2013., Split 2015.

Aleksandar JAKIR, „O nekim aspektima procesa oblikovanja nacionalnih identiteta na primjeru Dalmacije između dva svjetska rata", Nacija i nacionalizam u hrvatskoj povijesnoj tradiciji (ur. Tihomir Cipek i Josip Vrandečić), Zagreb 2007., 127-139.

Zdravka Jelaska Marijan, Grad i ljudi: Split 1918.-1941., Zagreb 2009.

Zdravka Jelaska Marijan, „Zemaljska vlada za Dalmaciju (2. studenoga 1918. - 20. siječnja 1919.), Godina 1918: prethodnice, zbivanja, posljedice. Zbornik radova s medunarodnoga znanstvenog skupa (ur. Zlatko Matijević), Zagreb 2010., 155-170.

Miljenko Jergović, „Vladan Desnica. Hitac veselnik. 'Zimsko ljetovanje', roman o dva svijeta koji više ne postoje, zadarskom i srpskom“, Magazin Jutarnjeg lista (Zagreb), 21. i 22. 6. 2014., 65.

Peter Jutronić, „Prikaz elektrifikacije Dalmacije i energetska situacija“, Zbornik Društva inženjera i tehničara u Splitu (ur. Slavko Sirišćević), Split 1958., 441-466.

Davor KRILE, „Sočanska bojišnica - najveće dalmatinsko groblje“, Slobodna Dalmacija (Split), 12. 4. 2014., 16-17.

Bogdan Krizman, Raspad Austro-Ugarske i stvaranje jugoslavenske države, Zagreb 1977.

Anatolij KudrJavcev, Vječni Split, Split 1985.

Stevan Kukoleča, Industrija Jugoslavije 1918-1938, Beograd 1941.

Ivo John Lederer, Yugoslavia at the Paris Peace Conference. A Study in Frontier Making, New Haven - London 1963.

Norka Machiedo Mladinić, „Oskar Tartaglia: od jugoslavenskog nacionalista do žrtve komunističke represije“, Časopis za suvremenu povijest, 35/2003., br. 3., 903-920.

Norka Machiedo Mladinić, „Životni put dr. Ive Tartaglie. Split, 6. II. 1880. - Lepoglava, 3. IV. 1949.“, Radovi zavoda za hrvatsku povijest, 26/1993., 281-288.

Dušan Marinković, „Biografija Vladana Desnice“, Hotimično iskustvo: diskurzivna proza Vladana Desnice. Knjiga druga (prir. Dušan Marinković), Zagreb 2006., 217-250.

Mijo Mirković, Ekonomska historija Jugoslavije, Zagreb 1962.

Mijo Mirković, Ekonomska struktura Jugoslavije 1918-1941, Zagreb 1950.

Hrvoje Morović, Grada za bibliografiju splitske periodike: novine 1875-1941, Split 1968.

Stijepo ОваD, Dalmatinsko selo u prošlosti, Split 1990. 
Stanko Piplović, Izgradnja Splita između svjetskih ratova, Split 2008.

Branislav Radica, Novi Split: monografija grada Splita od 1918-1930 godine, Split 1931.

Drago RoksAndić, „Dr. Uroš Desnica 1918. - 1921.: životopisne nedoumice na raskrižju epoha“, Spalatumque dedit ortum: zbornik povodom desete godišnice Odsjeka za povijest Filozofskog fakulteta u Splitu (ur. Ivan Basić i Marko Rimac), Split 2014., 499-511.

Ivo Rubić, Gravitacija susjednih žitelja Splita, Zagreb 1930.

Hodimir Sirotкović, „O nastanku, organizaciji, državnopravnim pitanjima i sukcesiji Države SHS nastale u jesen 1918.“, Časopis za suvremenu povijest, 24/1992., br. 3, 61-74.

Josip Smodlaka, Zapisi dra Josipa Smodlake (ur. Marko Kostrenčić), Zagreb 1972.

Statistika industrije Kraljevine Jugoslavije, sa adresarom industriskih preduzeća, Beograd 1941.

Dragovan ŠErić, Italija, saveznici i jugoslavensko pitanje, Zagreb 1970.

Zdenka Šımončić-Bobetкo, Agrarna reforma i kolonizacija u Hrvatskoj 1918.-1941., Zagreb 1997. Matej ŠKaRICA, Splitski shematizam za godinu 1923., Split 1923.

Filip ŠKıluan, Prvi svjetski rat u Dalmaciji (1914. - 1918.), Split - Dubrovnik 2014.

Anita Tićınović, Zbirka dalmatinskih novina u Sveučilišnoj knjižnici u Splitu, Split 2004. 